\title{
Antioxidant and Antifungal Activity of Naphthoquinones Dimeric Derived from Lawsone
}

\author{
Aldo S. de Oliveira ${ }^{1}$, Inês M. C. Brighente ${ }^{1}$, Rafael G. Lund ${ }^{2}$, Luana C. Llanes ${ }^{1}$, Ricardo J. Nunes ${ }^{1}$, \\ Lizandra C. Bretanha', Rosendo Augusto Yunes ${ }^{1}$, Pedro H. A. Carvalho' ${ }^{2}$, Juliana S. Ribeiro ${ }^{2}$ \\ ${ }^{1}$ Department of Chemistry, Center of Physical and Mathematical Sciences, Federal University of Santa Catarina, Florianópolis, SC, \\ Brazil \\ ${ }^{2}$ Oral Microbiology Laboratory, Faculty of Dentistry, Federal University of Pelotas, Pelotas, Brazil \\ Email: ^aldo.sena@ufsc.br
}

How to cite this paper: de Oliveira, A.S., Brighente, I.M.C., Lund, R.G., Llanes, L.C., Nunes, R.J., Bretanha, L.C., Yunes, R.A., Carvalho, P.H.A. and Ribeiro, J.S. (2017) Antioxidant and Antifungal Activity of Naphthoquinones Dimeric Derived from Lawsone. Journal of Biosciences and Medicines, $5,39-48$.

https://doi.org/10.4236/jbm.2017.52004

Received: December 23, 2016

Accepted: February 17, 2017

Published: February 20, 2017

Copyright $\odot 2017$ by authors and Scientific Research Publishing Inc. This work is licensed under the Creative Commons Attribution International License (CC BY 4.0).

http://creativecommons.org/licenses/by/4.0/

\begin{abstract}
This article reports the evaluation of antioxidant and antifungal activity from synthetic naphthoquinones derived from lawsone. The antifungal activity was carried out through the inhibition of exoenzymes produced by Candida albicans. The inhibition of phospholipase and the proteinase production by Candida was similar in all derivatives tested; however, the difference between the enzyme production of the control and test does not show statistical difference in any of the studied strains. Furthermore, the antioxidant activity using DPPH radical-scavenging assay showed an important activity for all naphtoquinone derivatives.
\end{abstract}

\section{Keywords}

Napthoquinones, Antifungal, Candida albicans, Antioxidant

\section{Introduction}

Though numerous naturally occurring compounds with biological activity have been investigated, many of them are not suitable for therapeutic use due to their toxic, carcinogenic and mutagenic properties. Nowadays, it is possible to make modifications of active chemical structures, in order to synthesize compounds with improved therapeutic activity and reduced toxicity [1].

The indiscriminate use of antifungal agents in the treatment of these infections has led to the development of drug resistance. Antifungal resistance can be described as a failure to respond to antifungal therapy [2].

Some cultures of Candida albicans have become resistant to antifungal agents, 
and in particular the triazole compounds, by the action of efflux pumps which reduce the accumulation of the drug, changes in the structure of the target protein and the antifungal composition of the membrane changes [3]. The clinical consequences of resistance to antifungal can be observed as treatment failures in patients and changes in the prevalence of Candida species causing disease [4]. Thus, given the current situation of resistance to drugs commonly used to combat Candida infections, great efforts have been made to develop new antimicrobial drugs in order to keep pace with the emergence of organisms that are resistant to current chemotherapeutics and to develop new chemical compounds that circumvent existing drug resistance mechanisms [4]. Recent studies support investigating drugs with specific targets, suggesting a change of focus to the development of new antifungal agents capable of inhibiting virulence factors. Moreover, industry has stimulated the development of new methods to identify and inhibit these virulence factors with lower doses of antimicrobials, aiming to avoid an increase in antifungal resistance [5].

Candida sp. develop specific virulence mechanisms that confer them the ability to colonise host epithelial cells, to invade deeper cells or to influence host defences [6]. The ability of Candida albicans to persist within the host and cause infection has been attributed to many virulence properties, which include: adhesion, dimorphism, the ability to switch between different morphological types, interference with the immune system, synergism and the production of extracellular enzymes, such as proteinases and phospholipases [7]. The exoenzymes have been shown to directly contribute to virulence of $C$. albicans [8]. The secreted proteinases are responsible for adhesion, tissue damage and invasion of host immune responses [9]. Their proteolytic activity has been associated with tissue invasion [10]. The secretion of extracellular phospholipases is considered a key attribute that aids in the invasion of the host mucosal epithelia. In general, phospholipases catalyse the hydrolysis of phospholipids, which are the major components of all cell membranes [11] [12]. So the amount of these enzymes is important as well as their presence [8].

The naphthoquinone is a functional constituent of several biochemical systems which can act as in the human defense system [13]. Several naphthoquinones have pharmacological properties as antibacterial, antifungal, antitumoral, or antiprotozoal agents [14]. The quinones are known to be electron transporters (e.g. ubiquinone, vitamin $\mathrm{K}$ ), and are essential for many enzymatic processes. They can act as anti- or pro-oxidants depending on the conditions of the media, and this chemical versatility gives them an important role in different biochemical processes that are essential to living organisms [15]. The oxidation state of some organic compounds, as napthoquinones, allows them to act by different mechanisms, such as: scavengers of free radicals, chelators of metal ions such as iron and copper, and also inhibitors of the enzymes responsible for the production of free radicals [16] [17]. This imbalance between the formation and removal of ROS (reactive oxygen species) causes damage to the cells at nucleic acids, proteins and membrane lipids, thus leading to many health problems as- 
sociated with ageing (carcinogenesis, cardiovascular and coronary diseases) [18].

Within this context, lawsone (2-hydroxy-1,4-naphtoquinone) is the principal active component of Lawsonia inermis Linn. (known as Henna). Studies have demonstrated lawsone to possess a number of interesting biological activities, such as antioxidant [19], antibacterial and antifungal [20], anti-inflammatory, antipyretic and analgesic [21], anticancer and cytotoxic [22]. Antioxidants play an important role in inhibiting or delaying oxidative stress that arises as a result of an imbalance between free radical production and antioxidant and repair defenses [23]. At low to moderate concentrations, reactive oxygen/nitrogen species, ROS/RNS, have beneficial effects, carrying functions in living systems [24]. Though, an overproduction of free radical species results in oxidative stress, process that can cause damage to all types of biomolecules, including proteins, enzymes, amino acids, lipids, DNA and carbohydrates [25]. Moreover, various pathological conditions as cardiovascular disease, diabetes, cancer, ageing and neurological disorders have been correlated to oxidative stress [26].

This paper describes the investigation of antioxidant activity of 3,3'-(arylmethylene)bis(2-hydroxynaphthalene-1,4-dione) derivatives, using DPPH radicalscavenging assay and investigates in vitro antifungal activity through the inhibition of exoenzymes produced by Candida sp.

\section{Experimental}

\subsection{Synthesis of Naphthoquinones Dimeric Derived from Lawsone}

In a flask, 2-hydroxynaphthalene-1,4-dione $(2 \mathrm{mmol})$, aldehyde $(1 \mathrm{mmol})$ and $\mathrm{LiCl}(1 \mathrm{mmol})$ were mixed with water $(5 \mathrm{~mL})$ under microwave irradiation at $70^{\circ} \mathrm{C}$ for $15 \mathrm{~min}$. The reaction progress was monitored by TLC. The precipitates obtained were filtered and washed with water and then with EtOH to afford the pure product (1-a to $1-\mathrm{i})$ [27].

\subsection{Antioxidant Assay}

The free radical scavenging activity of the samples was measured using DPPH (2,2-diphenyl-1-picrylhydrazyl) [28]. For this assay $1 \mathrm{~mL}$ of sample (in different concentrations) was added to $2 \mathrm{~mL}$ of a solution of DPPH in methanol $(0.004 \%)$. In order to subtract the absorbance promoted by the staining of the sample, a solution of methanol $(2.0 \mathrm{~mL})$ and the sample $(1.0 \mathrm{~mL})$ was used as the blank $\left(\mathrm{A}_{\text {blank }}\right)$. A solution of DPPH $(2.0 \mathrm{~mL})$ and methanol $(1.0 \mathrm{~mL})$ was used as the control $\left(\mathrm{A}_{\text {control }}\right)$ which is regarded as $100 \%$ of DPPH. The absorbance of the resulting solution $\left(\mathrm{A}_{\text {sample }}\right)$ was measured after $30 \mathrm{~min}$ at $517 \mathrm{~nm}$ and converted into percentage of antioxidant activity (AA) using the Equation (1):

$$
\mathrm{AA} \%=100-\left\{\left[\left(\mathrm{A}_{\text {sample }}-\mathrm{A}_{\text {blank }}\right) \times 100\right] / \mathrm{A}_{\text {control }}\right\} .
$$

Rutin and lawsone were used as standards. The radical scavenging activity was expressed in terms of the amount of antioxidants necessary to decrease the initial DPPH absorbance by $50 \%\left(\mathrm{EC}_{50}\right)$. 


\subsection{Antifungal Activity}

\subsubsection{Antifungal Agents}

A solution of compounds $1 \mathrm{a}-1 \mathrm{i}$ was prepared with concentrations of $5 \mathrm{mg} / \mathrm{mL}$ and $10 \mathrm{mg} / \mathrm{mL}$ in DMSO.

\subsubsection{Strains Culture Conditions}

Tests were carried out with one strain of Candida albicans (ATCC 62342) resistant to fluconazole and seven strains isolated from patients with dentures stomatitis at multiple affected sites and identified as Candida albicans. Strains are part of a fungi bank at the Oral Microbiology Laboratory at Federal University of Pelotas. Samples were kept under $-80^{\circ} \mathrm{C}$, reactivated at room temperature and a 20 $\mu \mathrm{L}$ aliquot was cultivated aerobically on SDA (Sabouraud dextrose agar) (Acumedia Manufactures, Inc, Michigan, USA) with $0.01 \%$ chloramphenicol added for $24 \mathrm{~h}$ at $37^{\circ} \mathrm{C}$

\subsubsection{Enzymatic Activity of Proteinases and Phospholipases}

For the test with proteinases, we used the agar medium containing $2 \mathrm{~g}$ of BSA (bovine serum albumin), $1.45 \mathrm{~g}$ of YNB (yeast nitrogen base, Difco Laboratories, Detroit), $20 \mathrm{~g}$ of glucose and $20 \mathrm{~g}$ of agar per litre of distilled water. The test medium for phospholipases consisted of SDA containing $57.3 \mathrm{~g}$ of sodium chloride, $0.55 \mathrm{~g}$ of calcium chloride, and $100 \mathrm{~mL}$ of $50 \%$ sterile egg yolk (egg yolk enrichment) per litre of distilled water. Test isolates were grown on SDA for $24 \mathrm{~h}$ and were suspended in $1 \%$ sterile PBS (phosphate buffered saline), with a refraction and visual turbidity equal to $0.5 \mathrm{McF}$ arland units. For each concentration, and starting with the greatest, $20 \mu \mathrm{L}$ of the yeast suspension (approximately 108 cells $/ \mathrm{mL}$ ) were emulsified in $1980 \mu \mathrm{L}$ of sterile PBS.

Eight strains of $C$. albicans (seven isolated from the oral cavity from patients with denture stomatitis and available in mycology collection of oral microbiology laboratory and oneATTC62342 strain resistant to fluconazol) were prepared in a cell suspension in a $0.5 \mathrm{McF}$ arland concentration. From this cell suspension, $0.5 \mathrm{~mL}$ was added to tubes containing $2 \mathrm{~mL}$ of PBS (control) and $2 \mathrm{~mL}$ of PBS/ naphtoquinone derivatives. This dilution resulted in a concentration of $10^{6}$ and $10^{7}$ cells $/ \mathrm{mL}$ in each assay tube. The tubes were then incubated for $30 \mathrm{~min}$ at $37^{\circ} \mathrm{C}$. The naphtoquinone derivative was then removed by two cycles of dilution with sterile PBS and centrifugation for $10 \mathrm{~min}$ at $3000 \mathrm{rpm}$. The supernatant was completely decanted and the yeast pellets were re-suspended in $2.5 \mathrm{~mL}$ of sterile PBS. The plates were incubated at $37^{\circ} \mathrm{C}$ for $48 \mathrm{~h}$ and $72 \mathrm{~h}$ for proteinases and phospholipases, respectively. The enzymatic activity was determined by the formation of a halo around the yeast colony. Results were measured at $48 \mathrm{~h}$ for verification of proteinase activity (Saps) and $72 \mathrm{~h}$ for verification of phospholipase activity (PLs). The enzyme production $(\mathrm{Pz})$, was calculated as previously described by Carvalho et al., 2016 [5], wherecd is thecolony diameter and ( $c d+p)$ is the diameter of the colony plus the precipitation diameter around the colony.

$$
\mathrm{Pz}=\mathrm{cd} / \mathrm{cd}+\mathrm{p}
$$

All $C$. albicans strains were tested in triplicate to verify the enzymatic activity 
of proteinases and phospholipases.

\subsection{Statistical Analysis}

In order to compare the groups, ANOVA test was performed as a complementary test Studen-Nweuman-Keuls and Tukey's. For statistical significance, a $\mathrm{p}$-value of $\mathrm{p}<0.05$ was considered.

\section{Results and Discussion}

\subsection{Synthesis of Naphtoquinones Derivatives (1-a to 1-i)}

The naphtoquinones derivatives 1-a to 1-i are shown in Scheme 1. The details of the synthesis of compounds have been reported previously [27].

\subsection{Antifungal Activity}

The resistance to antifungal agents and the changes in the prevalence of species Candida albicans are related as the causes of failure in the treatment of candidiasis.

The virulence factors of Candida are important in its pathogenesis. The production of extracellular enzymes as phospholipase and proteinasemay be highlighted as a major virulence factor of Candida. Various functions are assigned to these enzymes such as digestion and breakdown of molecules to pathogen nutrition, or even tissue invasion by destroying the cell membranes and also as a way to attack the host defense cells

It is assigned to some nafhthoquinones derivatives, antifungal, antiviral and
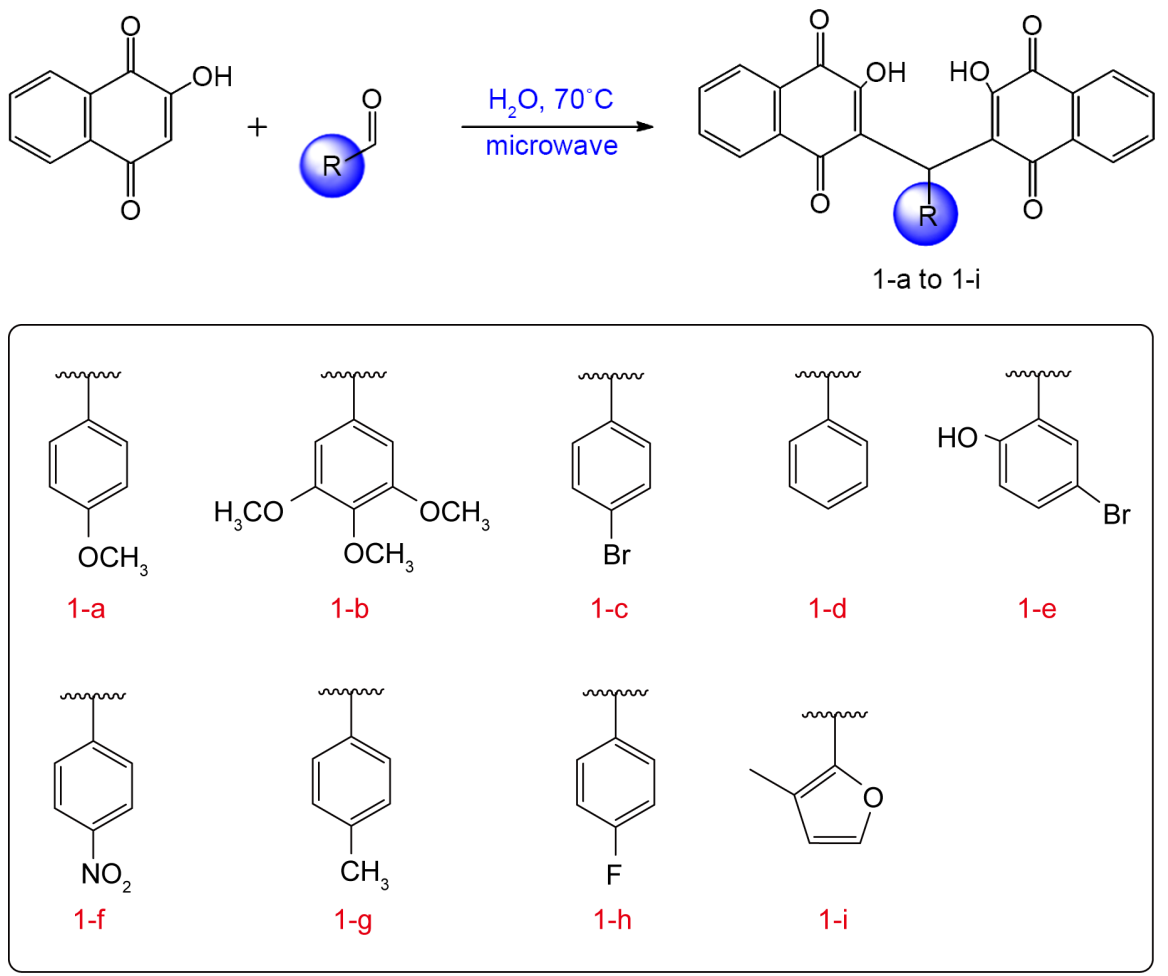

Scheme 1. Synthesis of compounds 1-a to 1-i. 
antibacterial properties, and the use of such derivatives as antimicrobial agents covering various areas of industry. However, these studies are limited as in most cases the antifungal tests used turbidity or minimum inhibitory concentration (MIC) and therefore cannot be compared with our study. The methodology for inhibiting phospholipase production was previously validated by Kadir et al. 2007 [29], demonstrating inhibition of the production of this enzyme by chlorhexidine in different concentrations and discoveringa statistically significant reduction in concentrations of $0.0012 \%$ and $0.002 \%$ from ten isolates of $C$. albicans.

Table 1 and Table 2 show the phospholipase and proteinase production $(\mathrm{Pz})$ respectively by Candida albicans strains when exposed to the control and the naphthoquinone derivatives (1a-1i) at different concentrations, $5 \mathrm{mg} / \mathrm{mL}$ and 10 $\mathrm{mg} / \mathrm{mL}$. The reduction in production of these enzymes by naphthoquinone derivatives at both concentrations tested was minimal. The difference between the enzyme production of the control and test does not show statistical difference in any of the studied strains.

It is important to make a comparison of the antimicrobial activity of a group when compared to another, because the test is done in stages, so that despite being used the same microorganism they are reactivated periodically and each reactivation activity can be present deferens. So we use control on all cards, but comparison of the steps would be an overestimation of the results. There are other studies in the literature which tests Candida antifungal activity through turbidity and the minimum inhibitory concentration test (MIC), however, despite of this diversity of the assays, this not allow us to compare our results to these studies.

Table 1. Reduction of phospholipase production by Candida albicans exposed to naphthoquinone derivatives $1 \mathrm{a}-1 \mathrm{i}$.

\begin{tabular}{cccccc}
\hline & Pz control & $\begin{array}{c}\text { Pz concentration } \\
(10 \mathrm{mg} / \mathrm{mL})\end{array}$ & $\begin{array}{c}\text { Pz concentration } \\
(5 \mathrm{mg} / \mathrm{mL})\end{array}$ & $\begin{array}{c}\text { Pz reduction } \\
(10 \mathrm{mg} / \mathrm{mL})\end{array}$ & $\begin{array}{c}\text { Pz reduction } \\
(5 \mathrm{mg} / \mathrm{mL})\end{array}$ \\
\hline 1 -a & $0.64 \pm 0.23$ & $0.64 \pm 0.12$ & $0.72 \pm 0.1$ & 0.004 & 0.078 \\
1 -b & $0.66 \pm 0,24$ & $0.60 \pm 0.06$ & $0.66 \pm 0.14$ & -0.060 & -0.002 \\
1 -c & $0.62 \pm 0.31$ & $0.72 \pm 0.19$ & $0.62 \pm 0.12$ & 0.102 & -0.005 \\
1 -d & $0.58 \pm 0.25$ & $0.58 \pm 0.09$ & $0.61 \pm 0.12$ & -0.003 & 0.035 \\
1 -e & $0.68 \pm 0.35$ & $0.72 \pm 0.16$ & $0.67 \pm 0.17$ & 0.039 & -0.014 \\
1 -f & $0.57 \pm 0.28$ & $0.55 \pm 0.10$ & $0.65 \pm 0.19$ & -0.013 & 0.080 \\
1 -g & $0.65 \pm 0.30$ & $0.64 \pm 0.19$ & $0.60 \pm 0.13$ & -0.007 & -0.047 \\
1 -h & $0.71 \pm 0.12$ & $0 \pm 0 *$ & $0.77 \pm 0.12$ & -0.709 & 0.057 \\
1 -i & $0.67 \pm 0.40$ & $0.72 \pm 0.26$ & $0.73 \pm 0.24$ & 0.058 & 0.064 \\
Lawsone & $0.60 \pm 0.18$ & $0.60 \pm 0.13$ & $0.60 \pm 0.13$ & 0.000 & 0.001 \\
\hline
\end{tabular}

${ }^{*}$ Data from the 1 -h compound in concentration $10 \mathrm{mg} / \mathrm{mL}$ result null due to infeasibility of the microorganism. 
Table 2. Reduction of proteinase production (Saps) by Candida albicans exposed to naphthoquinones derivatives $1 \mathrm{a}-1 \mathrm{i}$.

\begin{tabular}{cccccc}
\hline & Pz control & $\begin{array}{r}\text { Pz concentration } \\
(10 \mathrm{mg} / \mathrm{mL})\end{array}$ & $\begin{array}{c}\text { Pz concentration } \\
(5 \mathrm{mg} / \mathrm{mL})\end{array}$ & $\begin{array}{c}\text { Pz reduction } \\
(10 \mathrm{mg} / \mathrm{mL})\end{array}$ & $\begin{array}{c}\text { Pz reduction } \\
(5 \mathrm{mg} / \mathrm{mL})\end{array}$ \\
\hline 1 -a & $0.18 \pm 0.12$ & $0.21 \pm 0.05$ & $0.19 \pm 0.05$ & 0.028 & 0.014 \\
1 -b & $0.17 \pm 0.07$ & $0.17 \pm 0.04$ & $0.18 \pm 0.04$ & 0.000 & 0.012 \\
1 -c & $0.16 \pm 0.07$ & $0.17 \pm 0.05$ & $0.16 \pm 0.04$ & 0.003 & 0.002 \\
1 -d & $0 \pm 0^{* *}$ & - & - & 0.000 & 0.000 \\
1 -e & $0.16 \pm 0.11$ & $0.18 \pm 0.08$ & $0.16 \pm 0.02$ & 0.014 & -0.005 \\
1 -f & $0.15 \pm 0.06$ & $0.15 \pm 0.02$ & $0.15 \pm 0.03$ & 0.006 & -0.001 \\
1 -g & $0.15 \pm 0.03$ & $0.16 \pm 0.02$ & $0.15 \pm 0.02$ & 0.008 & -0.001 \\
1 -h & $0.19 \pm 0.06$ & $0 \pm 0 *$ & $0.20 \pm 0.06$ & -0.191 & 0.007 \\
$1-\mathrm{i}$ & $0.14 \pm 0.08$ & $0.16 \pm 0.06$ & $0.16 \pm 0.06$ & 0.019 & 0.019 \\
Lawsone & $0.43 \pm 0.21$ & $0.42 \pm 0.17$ & $0.50 \pm 0.13$ & -0.005 & 0.070 \\
\hline
\end{tabular}

${ }^{* *}$ Data from the 1-h compound in concentration $10 \mathrm{mg} / \mathrm{mL}$ result null due to infeasibility of the microorganism. ${ }^{* *}$ For compound $1 \mathrm{~d}$, there was no growth of the strain in the negative controls.

Despite the naphthoquinone derivatives do not show significant inhibition in the production of exoenzymes (proteinase and phospholipase), we cannot say that these derivatives do not have antimicrobial activity against other virulence factors of Candida sp. Besides that, it is recommended to perform further studies, which may include other virulence factors of these microorganisms and thus to determine which pathway inhibiting these compounds act.

\subsection{Antioxidant Activity}

The antioxidant activity was investigated using DPPH radical-scavenging assay. The results are shown in Table 3.

The antioxidant activity shown for naphtoquinones derivatives showed $\mathrm{EC}_{50}$ values comparable in magnitude to the standards rutin and BHT. Of the compounds tested, 1-i was the most active compound of the series. The compounds of the furan type have certain aromaticity, even though they lack full aromatic ring in its structure. This is because one of the electronic pairs of oxygen atom interact with the double bonds of the ring, which causes a certain relocation of these electrons, coming to a chemical behavior similar to a benzene molecule.

Derivatives lawsone presented relevant $\mathrm{EC}_{50}$. These results demonstrate the importance of electronic lawsone system, which allows delocalization of electron. In redox reactions, naphtoquinones can form two species: semi-quinone and hidroquinone (Scheme 2). The first reduction refers to the formation of the semi-quinone in a quasi-reversible process and the second refers to the formation of a radical dianion, that have more basic character and have greater reactivity compared to the semiquinone, as becomes liable to undergo a deprotonation reaction or reaction type acid-base. 
Table 3. Antioxidants activity of naphtoquinone derivatives 1-a to 1-i.

\begin{tabular}{cccc}
\hline & $\mathrm{EC}_{50}\left(\mu \mathrm{mol} \cdot \mathrm{L}^{-1}\right)$ & & $\mathrm{EC}_{50}\left(\mu \mathrm{mol} \cdot \mathrm{L}^{-1}\right)$ \\
\hline $1-\mathrm{a}$ & 30.27 & $1-\mathrm{g}$ & 44.98 \\
$1-\mathrm{b}$ & 22.83 & $1-\mathrm{h}$ & 55.21 \\
$1-\mathrm{c}$ & 37.11 & $\mathbf{1 - \mathrm { i }}$ & 11.52 \\
$1-\mathrm{d}$ & 51.64 & Lawsone & 62.05 \\
$1-\mathrm{e}$ & 44.70 & Rutin & 4.55 \\
$1-\mathrm{f}$ & 50.26 & BHT & 37.39 \\
\hline
\end{tabular}

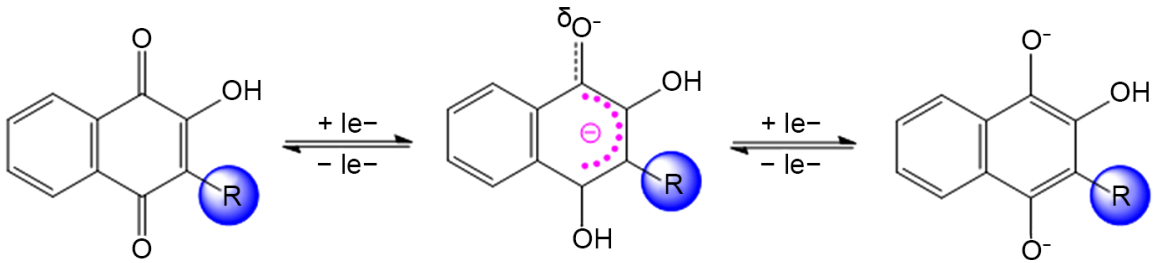

Scheme 2. Redox species from lawsone.

\section{Conclusion}

Derivatives from lawsone were evaluated for their antifungal and antioxidant activity. The compound 1-i derived from furan ring, and the compounds 1-a and 1-b, which possessed methoxyl, electron donor group in substituent benzene, showed better results for antioxidant activity. The combination of the data of the activities investigated demonstrates the possible therapeutic applicability of these compounds, and encourages further research to check a possible use of these compounds in control of antifungal diseases and other ageing diseases, especially considering the excellent antioxidant activity observed.

\section{Acknowledgements}

The authors thank CNPq for financial support.

\section{References}

[1] Ambrogi, V., Artini, D., De Carneri, I., Castellino, S., Dradi, E., Logemann, W., Meinardi, G., DI Somma, M. and Tosolini, G. (1970) Studies on the Antibacterial and Antifungal Properties of 1,4-Naphthoquinones. British Journal of Pharmacology, 40, 871-880. https://doi.org/10.1111/j.1476-5381.1970.tb10662.x

[2] Ghannoum, M.A. and Rice, L.B. (1999) Antifungal Agents: Mode of Action, Mechanisms of Resistance, and Correlation of These Mechanisms with Bacterial Resistance. Clinical Microbiology Reviews, 12, 501-517.

[3] Sanglard, D. and Odds, F.C. (2002) Resistance of Candida Species to Antifungal Agents: Molecular Mechanisms and Clinical Consequences. Lancet Infectious Diseases, 2, 73-85. https://doi.org/10.1016/S1473-3099(02)00181-0

[4] Kanafani, Z.A. and Perfect, J.R. (2008) Resistance to Antifungal Agents: Mechanisms and Clinical Impact. Clinical Infectious Diseases, 46, 120-128.

https://doi.org/10.1086/524071 
[5] Carvalho, P.H.A., Duval, A.R., Manzolli Leite, F.R., Nedel, F., Cunico, W. and Lund, R.G. (2016) (7-Chloroquinolin-4-yl) Arylhydrazones: Candida albicans Enzymatic Repression and Cytotoxicity Evaluation, Part 2. Journal of Enzyme Inhibition and Medicinal Chemistry, 31, 126-131. https://doi.org/10.3109/14756366.2015.1010527

[6] McManus, B.A., Maguire, R., Cashin, P.J., Claffey, N., Flint, S., Abdulrahim, M.H. and Coleman, D.C. (2012) Enrichment of Multilocus Sequence Typing Clade 1 with Oral Candida albicans Isolates in Patients with Untreated Periodontitis. Journal of Clinical Microbiology, 50, 3335-3344. https://doi.org/10.1128/JCM.01532-12

[7] Favero, D., França, E.J.G., Furlaneto-Maia, L., Quesada, R.M.B. and Furlaneto, M.C. (2011) Production of Haemolytic Factor by Clinical Isolates of Candida tropicalis. Mycoses, 54, e816-e820. https://doi.org/10.1111/j.1439-0507.2011.02035.x

[8] Uygun-Can, B., Kadir, T. and Gumru, B. (2016) Effect of Oral Antiseptic Agents on Phospholipase and Proteinase Enzymes of Candida albicans. Archives of Oral Biology, 62, 20-27. https://doi.org/10.1016/j.archoralbio.2015.11.006

[9] De Bernardis, F., Agatensi, L., Ross, I.K., Emerson, G.W., Lorenzini, R., Sullivan, P.A. and Cassone, A. (1990) Evidence for a Role for Secreted Aspartate Proteinase of Candida albicans in Vulvovaginal Candidiasis. Journal of Infectious Diseases, 161, 1276-1283. https://doi.org/10.1093/infdis/161.6.1276

[10] Mohandas, V. and Ballal, M. (2011) Distribution of Candida Species in Different Clinical Samples and Their Virulence: Biofilm Formation, Proteinase and Phospholipase Production: A Study on Hospitalized Patients in Southern India. Journal of Global Infectious Diseases, 3, 4-8. https://doi.org/10.4103/0974-777X.77288

[11] Maki, K. and Kaneko, S. (2013) Effective Concentration-Based Serum Pharmacodynamics for Antifungal Azoles in a Murine Model of Disseminated Candida albicans Infection. European Journal of Drug Metabolism and Pharmacokinetics, 38, 261-268. https://doi.org/10.1007/s13318-013-0122-4

[12] Silva-Rocha, W., et al. (2015) Effect of the Crude Extract of Eugenia Uniflora in Morphogenesis and Secretion of Hydrolytic Enzymes in Candida albicans from the Oral Cavity of Kidney Transplant Recipients. BMC Complementary Alternative Medicine, 15, 6. https://doi.org/10.1186/s12906-015-0522-x

[13] Elavarasan, S., Bhakiaraj, D. and Gopalakrishnan, M. (2013) Green Synthesis, Spectral Analysis of Some Novel Lawsone Derivatives and Its Anti-Mycobacterial Tuberculosis Activity.

[14] Morello, A., Pavani, M., Garbarino, J.A., Chamy, M.C., Frey, F., Mantilla, J., et al. (1995) Effects and Mode of Action of 1,4-Naphthoquinones Isolated from Calceolaria sessilis on Tumoral Cells and Trypanosoma Parasites. Comparative Biochemistry and Physiology Part C: Pharmacology, Toxicology and Endocrinology, 112, 119128. https://doi.org/10.1016/0742-8413(95)02003-9

[15] Lenaz, G., Fato, R., Baracca, A. and Genova, M. (2004) Mitochondrial Quinone Reductases: Complex I. Methods in Enzymology, 382, 3-20. https://doi.org/10.1016/S0076-6879(04)82001-9

[16] Gutteridge, J.M.C. and Halliwell, B. (2000) Free Radicals and Antioxidants in the Year 2000. A Historical Look to the Future. Annals of the New York Academy of Sciences, 899, 136-147. https://doi.org/10.1111/j.1749-6632.2000.tb06182.x

[17] Halliwell, B. and Gutteridge, J.M.C. (2006) Free Radicals in Biology and Medicine. 4th Edition, Oxford University Press, Oxford.

[18] Wang, S.Y. and Jiao, H. (2000) Scavenging Capacity of Berry Crops on Superoxide Radicals, Hydrogen Peroxide, Hydroxyl Radicals, and Singlet Oxygen. Journal of Agricultural and Food Chemistry, 48, 5677-5684.

https://doi.org/10.1021/jf000766i 
[19] Omar, M.A. (2005) Effect of 2-Hydroxy-1, 4-Naphthoquinone, a Natural Dye of Henna, on Aldehyde Oxidase Activity in Guinea Pig Liver. Journal of Medical Sciences, 5, 163-168. https://doi.org/10.3923/jms.2005.163.168

[20] Ambrogi, V., Artini, D., De Carneri, I., Castellino, S., Dradi, E., Logemann, W., Meinardi, G., DI Somma, M. and Tosolini, G. (1970) Studies on the Antibacterial and Antifungal Properties of 1,4-Naphthoquinones. British Journal of Pharmacology, 40, 871-880. https://doi.org/10.1111/j.1476-5381.1970.tb10662.x

[21] Ali, B.H., Bashir, A.K. and Tanira, M.O. (1995) Anti-Inflammatory, Antipyretic, and Analgesic Effects of Lawsonia inermis L. (Henna) in Rats. Pharmacology, 51, 356-363. https://doi.org/10.1159/000139347

[22] Kamei, H., Koide, T., Kojima, T., Hashimoto, Y. and Hasegawa, M. (1998) Inhibition of Cell Growth in Culture by Quinones. Cancer Biotherapy and Radiopharmaceuticals, 13, 185-188. https://doi.org/10.1089/cbr.1998.13.185

[23] Day, B.J. (2014) Antioxidant Therapeutics: Pandora's Box. Free Radical Biology and Medicine, 66, 58-64. https://doi.org/10.1016/j.freeradbiomed.2013.05.047

[24] Valkoa, M., Leibfritz, D., Moncola, J., Croninc, M. T. D., Mazura, M. and Telser, J. (2007) Free Radicals and Antioxidants in Normal Physiological Functions and $\mathrm{Hu}-$ man Disease. The International Journal of Biochemistry \& Cell Biology, 39, 44-84. https://doi.org/10.1016/j.biocel.2006.07.001

[25] Battin, E.E. and Brumaghim, J.L. (2009) Antioxidant Activity of Sulfur and Selenium: A Review of Reactive Oxygen Species Scavenging, Glutathione Peroxidase, and Metal-Binding Antioxidant Mechanisms. Cell Biochemistry and Biophysics, 55, 1-23. https://doi.org/10.1007/s12013-009-9054-7

[26] Dalle-Donne, I., Scaloni, A., Giustarini, D., Cavarra, E., Tell, G., Lungarella, G., Colombo, R., Rossi, R. and Milzani, A. (2005) Proteins as Biomarkers of Oxidative/ Nitrosative Stress in Diseases: The Contribution of Redox Proteomics. Mass Spectrometry Reviews, 24, 55-99. https://doi.org/10.1002/mas.20006

[27] De Oliveira, A., Llanes, L., Nunes, R., Yunes, R. and Brighente, I. (2014) Use of Ultrasound and Microwave Irradiation for Clean and Efficient Synthesis of 3,3' (Arylmethylene)bis (2-Hydroxynaphthalene-1,4-Dione) Derivatives. Green and Sustainable Chemistry, 4, 177-184. https://doi.org/10.4236/gsc.2014.44023

[28] Venzke, D., Carvalho, F.K., Ruani, A.P., Oliveira, A.S., Brighente, I.M.C., Micke, G.A., Barison, A. and Pizzolatti, M.G. (2013) PAMPA Permeability, Acetylcholinesterase Inhibition and Antioxidant Activity of Pyranoisoflavones from Polygala molluginifolia (Polygalaceae). Journal of the Brazilian Chemical Society, 24, 1991-1997.

[29] Kadir, T., Gümrü, B. and Uygun-Can, B. (2007) Phospholipase Activity of Candida albicans Isolates from Patients with Denture Stomatitis: The Influence of Chlorhexidine Gluconate on Phospholipase Production. Archives of Oral Biology, 52, $691-$ 696. https://doi.org/10.1016/j.archoralbio.2006.12.008 
Submit or recommend next manuscript to SCIRP and we will provide best service for you:

Accepting pre-submission inquiries through Email, Facebook, LinkedIn, Twitter, etc. A wide selection of journals (inclusive of 9 subjects, more than 200 journals)

Providing 24-hour high-quality service

User-friendly online submission system

Fair and swift peer-review system

Efficient typesetting and proofreading procedure

Display of the result of downloads and visits, as well as the number of cited articles Maximum dissemination of your research work

Submit your manuscript at: http://papersubmission.scirp.org/

Or contact jbm@scirp.org 